\title{
State Environmental Expenditures in New England and Their Relationship to Other Programmatic and Political Metrics
}

\author{
Robert P. Blauvelt \\ GEI Consultants, USA \\ E-mail: rblauvelt@geiconsultants.com
}

Received: May 20, 2020

Accepted: August 1, 2020

Published: August 5, 2020

doi:10.5296/jee.v11i2.17110

URL: https://doi.org/10.5296/jee.v11i2.17110

\begin{abstract}
State environmental agencies have developed into one of the primary mechanisms by which public health and quality of life is managed and protected within the United States. This analysis attempts to provide some understanding of what economic and political factors may be influencing funding for state environmental agencies in six New England states: Connecticut, Maine, Massachusetts, New Hampshire, and Vermont. The demographic makeup of New England, an area that is relatively well-off, highly educated, socially liberal, and diverse, make it the ideal place to test the relationships between state environmental agency spending and other key economic and political metrics.

Financial data sets evaluated as part of this study include state spending on 11 common programmatic areas. Non-financial data sets in this analysis include the percentage of voters casting ballots by political party for Democratic presidential candidates, U.S. Senators, U.S Representatives, and Governors, as well as the composition by political party of the upper and lower houses of state legislatures. A Pearson's product moment correlation coefficient was used to compare each state's environmental expenditures with the 17 independent variable data sets.

Natural Resource spending was positively correlated with Education spending in five states. Total (state) Expenditures also correlate positively with Natural Resource spending. General Revenues, similar to Total Expenditures, positively correlate with Natural Resource spending in five states, suggesting that state environmental agencies are effective bureaucratically in lobbying for and obtaining needed funding. State environmental agencies funding correlated positively with the percent of the electorate voting for the Democratic Presidential candidate in Connecticut, Maine, Massachusetts, New Hampshire, and Rhode Island. This correlation is similar to those noted by other researchers, but the remaining state-level political data sets
\end{abstract}


were less useful in establishing potential relationships.

Keywords: New England, State environmental agency, Economic, Political, Metrics

\section{Introduction}

By design, necessity, or happenstance, state environmental agencies have developed into one of the primary mechanisms by which public health and quality of life is managed and protected within the United States. These regulatory agencies and bureaus serve as first-responders during and after environmental disasters (man-made or natural), track and identify individuals and businesses that violate anti-pollution statutes, and function as scientific and data-gathering centers for policy makers. The vigor of state environmental agencies budgets also has been used as one of numerous surrogate measures of a state's environmental commitment or "greenness" (Patten, 1998; Newmark \& Witko, 2007; Woods $\&$ Konisky, 2012). The analysis presented in this study attempts to provide some understanding of what economic and political factors may be influencing funding for state environmental agencies in six New England states.

State environmental agency budgets are set through annual budgetary processes and determine program priorities and initiatives which can vary from inspecting hazardous waste storage facilities to keeping parks and waterways clear of litter. While governors and legislators have significant power to establish or set environmental agency funding levels, they do not get free reign. Policy-makers must operate within a framework of a watchful press, interest groups of varying strengths and effectiveness and, importantly, one that respects the numerous federal programs over which the majority of states have assumed control (e.g., Clean Air Act, Clean Water Act).

A complete understanding of the dynamics associated with setting a state's environmental agency spending priorities will be unique to each jurisdiction. A single or even extensive set of metrics will not be able to capture the subtleties related to the complex political ballet within a state-house, budget committee, or chief executive's office. However, as with any constituent service program competing for scarce resources, there are underlying forces that likely will arrange the funding stage and influence budgetary choreography. State programs are guided by a common base line: federal environmental regulations (Steinway \& Bots, 2005). While this baseline can be modified at the state level by cultural attitudes and political leanings, the desirability of a clean environment, similar to public safety, access to health care, and quality education, is not in question. It is this more common, although not universal, subset of economic and political state environmental agency disbursement drivers that are being sought.

\section{Study Area Characteristics}

The U.S. Census Bureau (USCB) has grouped six northeastern states into a region labelled New England that includes Connecticut (CT), Maine (ME), Massachusetts (MA), New Hampshire (NH), and Vermont (VT) (Figure 1). 


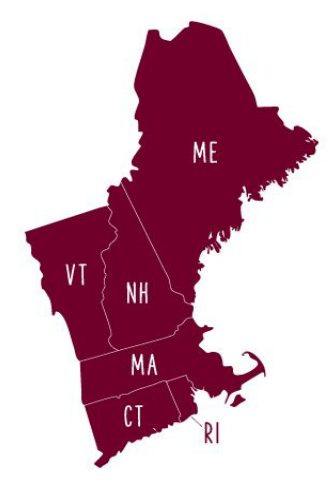

Figure 1. Index Map of New England Region

New England has a population density higher than that of the U.S. at 80 people per square mile (128 people per square $\mathrm{km}$ ) with densities decreasing in the western parts of the region. Its estimated (2018) population of 14.8 million is 49 percent male and 51 percent female. Approximately 20 percent of the population is under 18 years of age with about 17 percent 65 or older. White Americans make up 81 percent of New England's inhabitants with African Americans comprising seven percent . The largest ethnic minority in New England, 11 percent, are Hispanics and Latinos. Asian Americans are five percent of the population with Native Americans represented at about 0.3 percent. New England's European American residents are ethnically diverse, made up of people identifying as descending from Ireland, Italy, France, or England. Smaller but significant populations of people claiming Germany, Poland, or Portugal as their ancestral homeland live throughout the region as well (USCB, 2019).

Starting in the first half of the $20^{\text {th }}$ century, as manufacturing companies relocated to the Midwest and southern United States, New England's economy began to transition from one relying primarily on natural resources (e.g., seafood, building materials) and textiles. By the late 1990s, the regional economy was based on technology (computer and electronic equipment manufacturing), military defense research and development, finance and insurance, education, and health services.

The U.S. Department of Commerce (USDOC) has called New England a microcosm of the entire U.S. economy with about half of New England's exports consisting of industrial and commercial machinery, such as computers and related electronic components (USDOC, 2002). This, when combined with chemicals and transportation equipment, makes up about three-quarters of the region's industrial output. The service industry is a major economic driver as well and includes tourism, education, finance and insurance, plus architectural, building, and construction services.

The six New England states 2018 median household income was \$68,700, almost nine percent higher than the U.S. national average of \$63,200 (USCB Ref). New England has the highest percentage of residents with a bachelor's degree or more of any region of the country. The region's ranking among the nine Census divisions went from third in 1970 to second in 1980 to first in 1990 and this area continues to rank first in the nation, albeit other states are closing the educational gap (Kodrzycki, 2000). These six states are the most socially 
progressive in the United States, with more New Englanders identifying as liberals than Americans in other areas. In 2010, four of six of the New England states (Connecticut, Massachusetts, Rhode Island, and Vermont) were polled as the most liberal in the United States with the majority of state and national politicians elected from the Democratic Party. (USCB, 2019).

The demographic makeup of New England - a relatively well-off, highly educated, socially liberal, diverse population - make it the ideal area to test the relationships between state environmental agency spending and other key economic and political metrics.

\section{Data Sets}

Information on state spending, voting, and governmental composition between 1978 and 2016 was compiled primarily from the U.S. Census Bureau Statistical Abstract of the United States (USCB (A), 1978 - 2012) as well as from the USCB annual survey of state government finances (USC(B), 1978 - 2016). Voting records and state government political party composition post-2012 were gathered from on-line resources maintained by the National Governors Association (NGA, 2020) and National Conference of State Legislatures (NCSL, 2020). Descriptions of each data set are provided on the USCB web-site (USCB, 2020) and are summarized on Table 1. The 1978 through 2016 time frame was selected to provide a statistically meaningful data set -38 years - as well as to encompass potential effects of the 1981, 1990, 2001 and 2008 economic downturns.

Table 1. Summary of U.S. Census Bureau Data Set Definitions

\begin{tabular}{|c|c|}
\hline Metric & Definition \\
\hline Corrections & $\begin{array}{l}\text { Spending on confinement and rehabilitation of adults and minors } \\
\text { convicted of offenses against the law, and pardon, probation, and } \\
\text { parole activities. }\end{array}$ \\
\hline Educational & $\begin{array}{l}\text { Spending for elementary and secondary education, colleges, and } \\
\text { other educational institutions (e.g., for handicapped individuals), } \\
\text { and educational programs for adults, veterans, and other special } \\
\text { classes. }\end{array}$ \\
\hline General Revenue & $\begin{array}{l}\text { All government revenue received except liquor stores revenue, } \\
\text { insurance trust revenue, and utility revenue. }\end{array}$ \\
\hline $\begin{array}{l}\text { Government } \\
\text { Administration }\end{array}$ & $\begin{array}{l}\text { Disbursements for financial administration, judicial and legal, } \\
\text { and general public buildings; and activities of the governing } \\
\text { body, office of the chief executive, and central staff services and } \\
\text { agencies concerned with personnel administration, recording, } \\
\text { planning, zoning, and the like. }\end{array}$ \\
\hline Health & $\begin{array}{l}\text { Expenditures on outpatient health services, other than hospital } \\
\text { care, including public health administration; research and } \\
\text { education; categorical health programs; treatment and } \\
\text { immunization clinics; nursing; environmental health activities; }\end{array}$ \\
\hline
\end{tabular}




\begin{tabular}{|c|c|}
\hline Metric & Definition \\
\hline & $\begin{array}{l}\text { ambulance service, and other general public health activities } \\
\text { such as mosquito abatement. }\end{array}$ \\
\hline Highways & $\begin{array}{l}\text { Spending for construction, maintenance, and operation of } \\
\text { highways, streets, and related structures, including toll } \\
\text { highways, bridges, tunnels, ferries, street lighting and snow and } \\
\text { ice removal. }\end{array}$ \\
\hline Hospital & $\begin{array}{l}\text { Spending for confinement and correction of adults and minors } \\
\text { convicted of offenses against the law, and pardon, probation, and } \\
\text { parole activities. }\end{array}$ \\
\hline Natural Resource & $\begin{array}{l}\text { Spending related to conservation, promotion, protection, and } \\
\text { development of natural resources. Includes environmental, } \\
\text { irrigation, drainage, flood control, forestry and fire protection, } \\
\text { soil reclamation, soil and water conservation, fish and game } \\
\text { programs, and agricultural fairs. }\end{array}$ \\
\hline Police Protection & $\begin{array}{l}\text { Spending for preservation of law and order and traffic safety. } \\
\text { Includes police patrols and communications, crime prevention } \\
\text { activities, detention and custody of persons awaiting trial, traffic } \\
\text { safety, and vehicular inspection. }\end{array}$ \\
\hline Population & $\begin{array}{l}\text { The number of all people, male and female, child and adult, } \\
\text { living in a given geographic area. }\end{array}$ \\
\hline Public Welfare & $\begin{array}{l}\text { Spending for persons contingent upon their need. Excludes } \\
\text { pensions to former employees and other benefits not contingent } \\
\text { on need. Includes payments to other governments for welfare } \\
\text { purposes, administration, support of private welfare agencies, and } \\
\text { other services. }\end{array}$ \\
\hline Total Expenditures & $\begin{array}{l}\text { All money paid out by a state government (net of recoveries and } \\
\text { other correcting transactions) other than for retirement of debt, } \\
\text { investment in securities, extension of credit, or as agency } \\
\text { transactions. Includes only external transactions and excludes } \\
\text { noncash transactions such as the provision of perquisites or other } \\
\text { payments in kind. }\end{array}$ \\
\hline Voter & $\begin{array}{l}\text { Any person } 18 \text { years old or older who cast a ballot in a federal or } \\
\text { state election, includes Armed Forces stationed in the U.S. }\end{array}$ \\
\hline
\end{tabular}

Non-financial data sets in this analysis include the percentage of voters casting ballots by political party for Democratic presidential candidates, U.S. Senators, U.S Representatives, and Governors, as well as the composition by political party of the upper and lower houses of state legislatures. 


\section{Statistical Treatment}

Summary statistics consisting of mean, median, mode (when appropriate), standard deviation, variance, etc. were calculated for each New England state's environmental (natural resource) expenditures - the dependent variable - as well as the 17 associated independent variables. As might be expected when dealing with state-scale (macro) economic and sociopolitical factors, these statistics largely describe data sets that change slowly over the almost 40-year time interval (1978-2016) being evaluated, with few dramatic swings in value. Standard deviations and standard errors generally are low with tight (low) 95 percent confidence intervals. Skewness and kurtosis ranges indicate data sets are normally distributed.

A Pearson's product moment correlation coefficient (r) was used to compare each state's environmental expenditures with the 17 independent variable data sets. This statistic is a dimensionless index that ranges from -1 to 1 inclusive and reflects the extent of a linear relationship between two data sets. It can be described as the covariance of the two variables divided by the product of their standard deviations where +1 is total positive correlation, 0 is no correlation, and -1 is total negative correlation.

Like many commonly used statistics, the Pearson's product moment is not particularly robust (Wilcox, 2005), so its value can be misleading if outliers are present. However, inspection of scatterplots between $X$ 's (state environmental expenditures) and Y's (independent variable data sets) did not point to a situation where lack of robustness might be an issue. That is, outliers were not commonly observed or present in the independent or dependent variable data sets.

Correlation coefficients $(\rho \leq 0.05)$ for the financial metrics of the six New England states are shown on Table 2. Partial correlations also were calculated and are shown (where applicable) in parenthesis.

Table 2. Correlations among New England States Environmental Agencies Spending and Economic Metrics

\begin{tabular}{|c|c|c|c|c|c|c|}
\hline $\begin{array}{l}\text { Financial } \\
\text { Metric }\end{array}$ & Connecticut & Maine & Massachusetts & $\begin{array}{l}\text { New } \\
\text { Hampshire }\end{array}$ & $\begin{array}{l}\text { Rhode } \\
\text { Island }\end{array}$ & Vermont \\
\hline Corrections & 0.60 & 0.85 & 0.81 & 0.81 & 0.89 & --- \\
\hline Education & 0.80 & 0.83 & 0.80 & 0.81 & 0.82 & --- \\
\hline $\begin{array}{l}\text { General } \\
\text { Revenue }\end{array}$ & 0.70 & -0.58 & 0.85 & 0.80 & 0.81 & 0.73 \\
\hline $\begin{array}{l}\text { Govt. } \\
\text { Admin. }\end{array}$ & 0.76 & 0.94 & 0.92 & 0.79 & 0.82 & --- \\
\hline Health & 0.70 & $\begin{array}{l}0.90 \\
(0.57)\end{array}$ & --- & --- & --- & --- \\
\hline Highways & --- & $\begin{array}{l}0.87 \\
(0.49)\end{array}$ & 0.60 & 0.72 & 0.74 & --- \\
\hline
\end{tabular}




\begin{tabular}{|lllllll|}
\hline $\begin{array}{l}\text { Financial } \\
\text { Metric }\end{array}$ & Connecticut & Maine & Massachusetts & $\begin{array}{l}\text { New } \\
\text { Hampshire }\end{array}$ & $\begin{array}{l}\text { Rhode } \\
\text { Island }\end{array}$ & Vermont \\
\hline Hospital & 0.66 & -0.61 & --- & $\begin{array}{l}-0.56 \\
(0.47)\end{array}$ & -0.75 & 0.67 \\
\hline $\begin{array}{l}\text { Police } \\
\text { Protection }\end{array}$ & 0.76 & 0.90 & 0.80 & 0.78 & 0.74 & --- \\
\hline Population & 0.74 & 0.84 & 0.84 & 0.82 & 0.87 & -0.57 \\
\hline $\begin{array}{l}\text { Public } \\
\text { Welfare }\end{array}$ & 0.68 & 0.87 & 0.72 & 0.71 & 0.67 & --- \\
\hline $\begin{array}{l}\text { Total } \\
\text { Expenditures }\end{array}$ & $\begin{array}{l}(-0.78 \\
(0.49)\end{array}$ & 0.87 & 0.84 & & & \\
\hline
\end{tabular}

Correlation coefficients $(\rho<0.05)$ for the political metrics of the six New England states are listed on Table 3. Partial correlations, where appropriate, are shown in parenthesis on the table.

Table 3. Correlations among New England States Environmental Agencies Spending and Political Metrics

\begin{tabular}{|c|c|c|c|c|c|c|}
\hline $\begin{array}{l}\text { Political } \\
\text { Metric }\end{array}$ & Connecticut & Maine & Massachusetts & $\begin{array}{l}\text { New } \\
\text { Hampshire }\end{array}$ & $\begin{array}{l}\text { Rhode } \\
\text { Island }\end{array}$ & Vermont \\
\hline $\begin{array}{l}\% \quad \text { Voting } \\
\text { Democratic } \\
\text { President }\end{array}$ & 0.66 & 0.80 & 0.84 & 0.87 & 0.77 & $\begin{array}{l}-0.61 \\
(-0.64)\end{array}$ \\
\hline $\begin{array}{l}\% \quad \text { Voting } \\
\text { Democratic } \\
\text { Senator }\end{array}$ & --- & --- & --- & --- & --- & --- \\
\hline $\begin{array}{l}\% \quad \text { Voting } \\
\text { Democratic } \\
\text { Representative }\end{array}$ & --- & 0.76 & --- & --- & 0.68 & --- \\
\hline $\begin{array}{l}\% \quad \text { Voting } \\
\text { Democratic } \\
\text { Governor }\end{array}$ & --- & -0.59 & --- & --- & --- & --- \\
\hline $\begin{array}{l}\text { Composition } \\
\text { of State Upper } \\
\text { House } \\
\text { (Democratic) }\end{array}$ & --- & --- & --- & --- & --- & --- \\
\hline Composition & --- & --- & --- & --- & 0.51 & -0.63 \\
\hline
\end{tabular}




\begin{tabular}{|lllllll|}
\hline $\begin{array}{l}\text { Political } \\
\text { Metric }\end{array}$ & Connecticut & Maine & Massachusetts & $\begin{array}{l}\text { New } \\
\text { Hampshire }\end{array}$ & $\begin{array}{l}\text { Rhode } \\
\text { Island }\end{array}$ & Vermont \\
\hline
\end{tabular}

of State Lower

House

(Democratic)

\section{Findings}

Natural Resource spending was positively correlated with Education spending in five states. This relationship has been discussed extensively by others (Bacot \& Dawes, 1997; Newmark \& Witco, 2007; and Gallagher et al., 2013) and is reaffirmed in these findings. Total (state) Expenditures also correlate positively with Natural Resource spending and simply may reflect a relationship between the natural growth of state budgets over time rather than any special commitment to environmental protection. This seems to be borne out by similar, positive relationships among other programs not readily connected to the environment: Population, Corrections, Highways, Public Welfare, and Police Protection. Although the negative correlations between Natural Resource and Hospital spending reported in Maine, New Hampshire, and Rhode Island might indicate that environmental agency funding takes place at the expense of that program.

General Revenues, similar to Total Expenditures, positively correlate with Natural Resource spending in five states (including Vermont), suggesting that state environmental agencies are effective bureaucratically in lobbying for and obtaining their pieces of the taxpayer pie. Maine is the economic outlier in these correlations, oddly showing a negative correlation between Natural Resource spending and General Revenues. The reason for this is not apparent in the data, especially since Maine's spending on overall Government Administration, as seen also in Connecticut, Massachusetts, New Hampshire, and Rhode Island, is positively correlated with Natural Resource expenditures. The relationship between Health spending and Natural Resources is present, and positive, in only Connecticut and Maine, so this metric is not very applicable for the New England region.

Product moment correlations between Natural Resource spending and six political metrics (Table 2) also was conducted. The independent variables were chosen because of the widely held belief that politicians aligned with the Democratic Party will tend to support more aggressive environmental policy initiatives (Dell, 2009). State environmental agencies funding correlated positively with the percent of the electorate voting for the Democratic Presidential candidate in Connecticut, Maine, Massachusetts, New Hampshire, and Rhode Island. This correlation is similar to those noted by other researchers (Carter, 2007; Bomberg \& Schlosberg, 2008). The relationship between votes for Democratic Presidential candidates and Natural Resource spending was negative in Vermont and remained strong even when corrected for the effects of the other five independent variables (partial correlation -0.64 at $\alpha$ $<0.05)$.

The majority of governorships in Connecticut, Massachusetts, New Hampshire, and Vermont were held by Democrats (Figure 2) during the study period (1978-2016). The political affiliations of governors in Maine and New Hampshire were evenly split between Democrats 
and Republicans during this time.

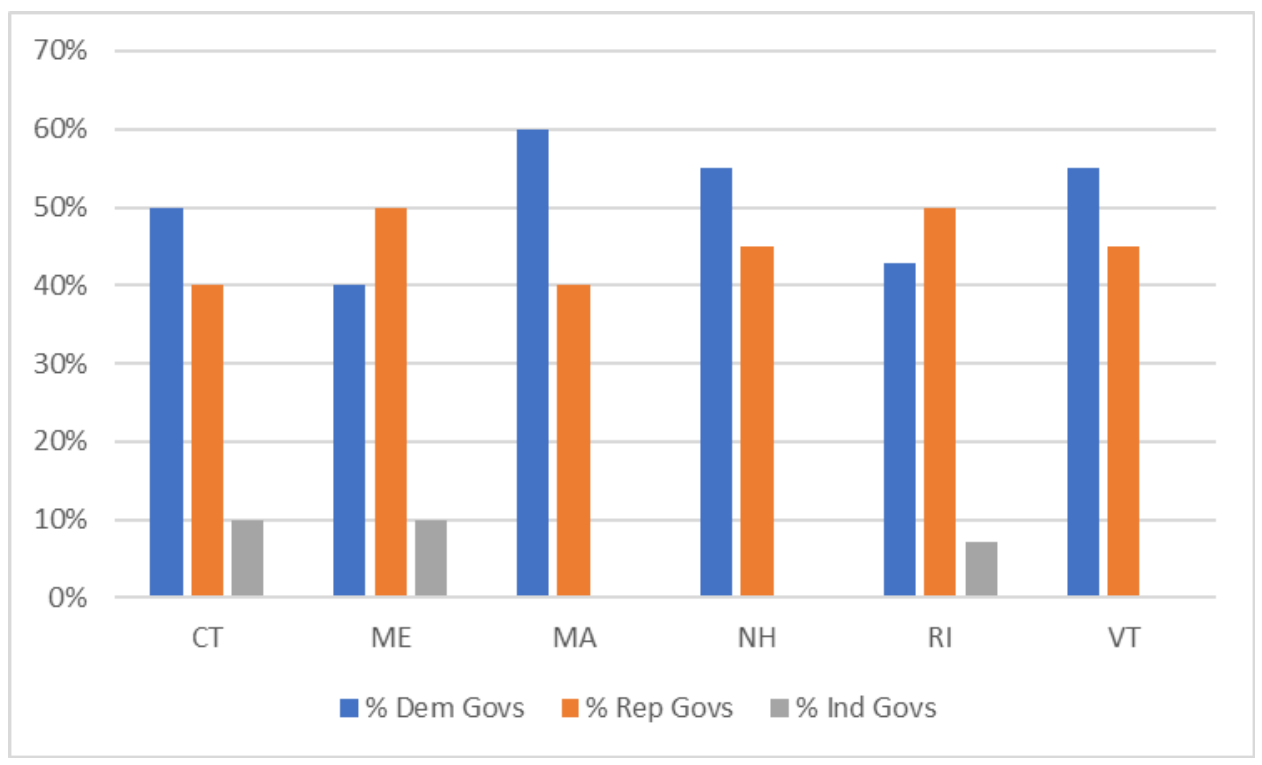

Figure 2. Political Affiliations - New England Governors (1978-2016)

State legislative bodies, upper and lower houses, overwhelmingly were Democratic in Connecticut, Maine, Massachusetts, Rhode Island, and Vermont (Figure 3) during the 38-year study period.

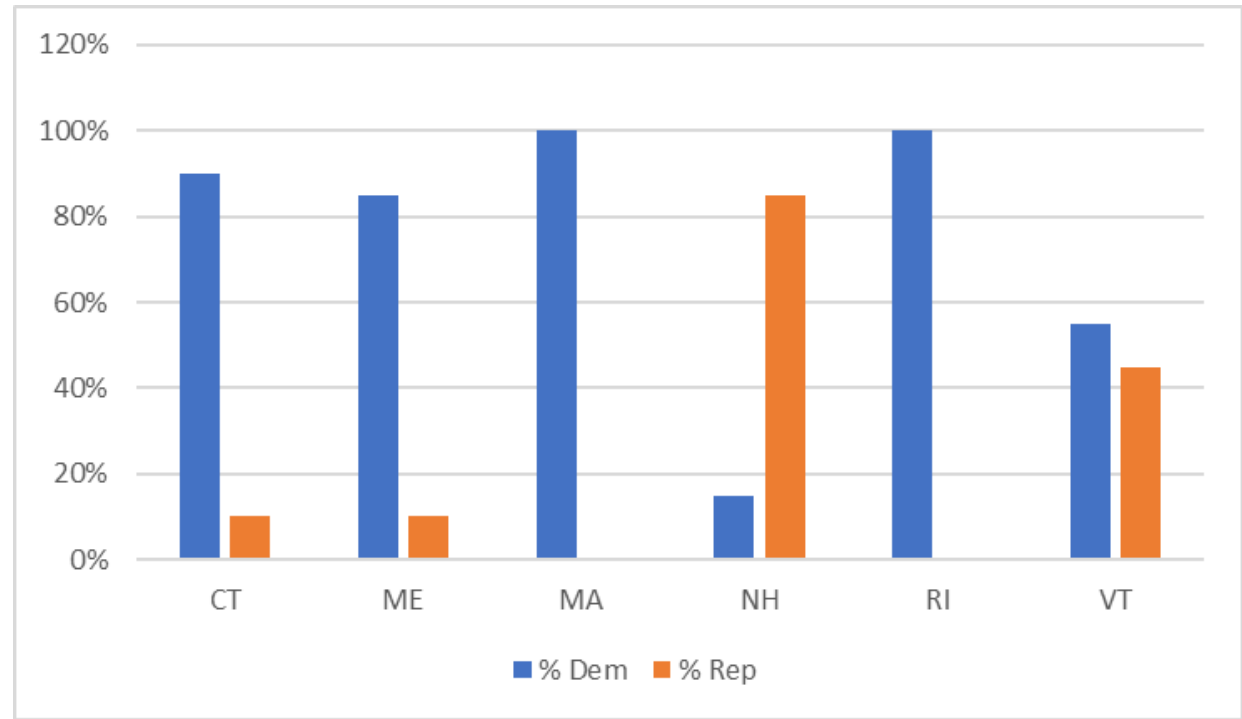

Figure 3. Political Affiliations - New England State Legislatures, Lower House 


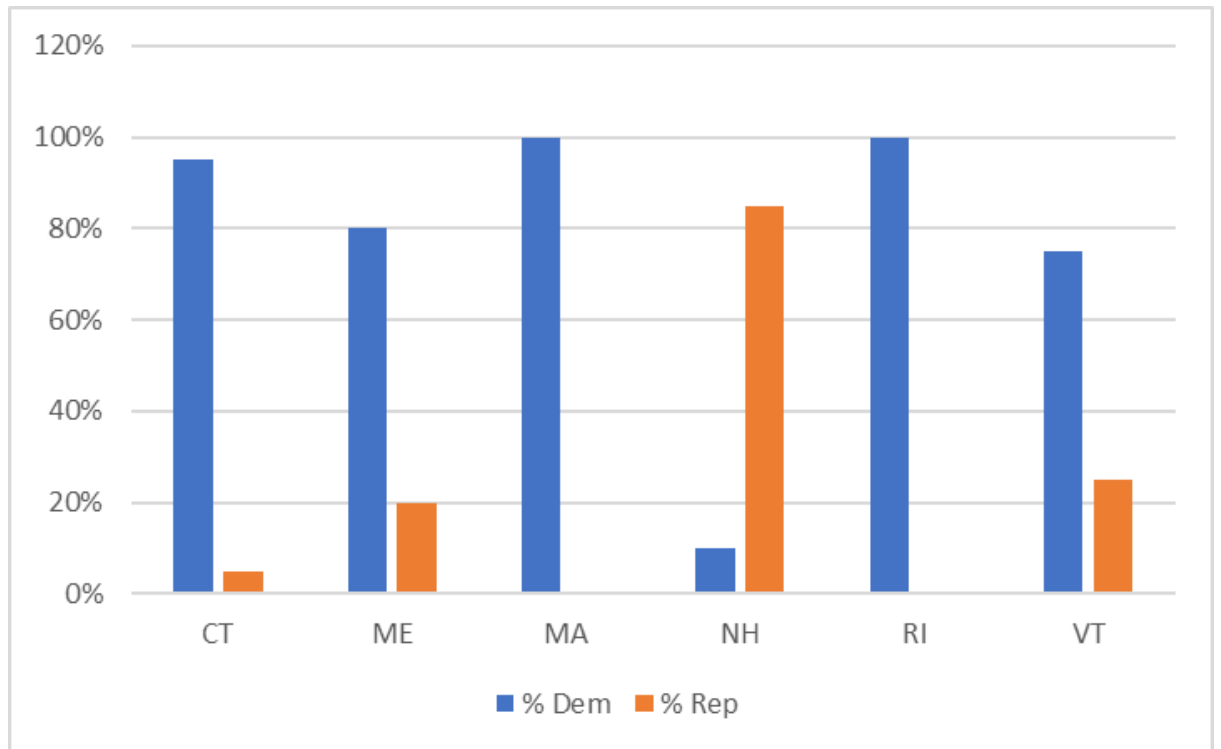

Figure 4. Political Affiliations - New England State Legislatures, Upper House

New Hampshire is the lone political outlier, with the majority of upper and lower state legislative bodies held by Republicans. However, since the early 1990s, New Hampshire's politics has switched from staunchly Republican to "swing state" status (Jacobson, 2013) and despite this Republican legacy, New Hampshire has a long history of social liberalism. In recent presidential elections, New Hampshire supported Bill Clinton (D) in 1992 and 1996, John Kerry (D) in 2004, and Barack Obama (D) in 2008 and 2012. New Hampshire also elected two Democrats to the Governorship during this period. At the end of the 2008 election cycle, voters registered as Democrats outnumbered those registered as Republicans. New Hampshire also is known for its libertarian tendencies coupled with fiscal restraint. For example, the state has no income tax as well as no laws requiring automobile insurance, seat-belt usage, or wearing motorcycle-helmets. Same-sex civil unions were authorized in 2008 and same sex marriage became legal in 2010, five years before the Supreme Court decision affirming this right.

As noted above, percent voting for the Democratic Party presidential candidate was the independent variable that most frequently correlated with Natural Resource spending. The remaining political data sets were less useful in establishing potential relationships. This may be due to the long established status of the Democratic Party in this liberal region of the United States. Over the study period (1978 through 2016) Congressional delegations, governor's offices, and state legislative houses were dominated by politicians aligned with those from the Democratic Party. Or in New Hampshire's case, candidates with a strong tendency toward social libertarianism regardless of political party affiliation. While the odd election here and there resulted in the occasional, short-term flips to Republican party control, the Democratic party clearly retained its' supremacy over the long run in the majority of state elective offices. Environmental agency spending at the state house and Congressional levels in New England may therefore be less influenced by party politics and more directly related to the effectiveness of the state environmental agency during the give and take of bureaucratic and policy infighting that occurs during the budgeting process (Nicholson-Crotty 
\& Miller, 2012).

\section{Discussion}

State environmental agency expenditures can serve as a multi-dimensional representation of the budget preferences of legislators and governors and are readily comparable across jurisdictions thanks to the regulatory "floor" set by federal mandates and standards. Examining state environmental agency expenditures over time lessens the likelihood that findings are due to some catastrophic political or environmental condition but rather are consistently held internal and external policy or philosophical elements reflective of, in some measure, constituent viewpoints.

Although there is no single way to measure a state's commitment to environmental protection, money probably is more reliable than most others. And it has been the intent of this analysis to evaluate the relationship between environmental agency expenditures (money) and the influence of external factors or drivers on those expenditures in New England. The results are not indicative of a direct, consistent effect. Rather, they are expressed through the integration of a set of blended metrics focused on economic attributes and political factors that are roughly consistent across this limited geography. Such a basic understanding of the forces that may be influencing state environmental spending, even at this broadest of views, could provide state officials an increased awareness of the breadth of drivers within their borders (regions) and offer some insight and appreciation into the values of their consistency.

Correlations between the independent and dependent variables are not present in all states and some states show stronger relationships than others. This suggests a complicated, multifaceted relationship. As a group, however, the independent variables do seem to correlate with changes in state environmental agency expenditures. While there may be missing factors that could raise the values of the correlation coefficients or increase the number of correlations per state, it is more likely that these data sets have captured the most significant driving forces in this relationship and could be representative of a more complex picture of how state environmental agencies expenditures (funding levels) are established.

\section{References}

Bacot, A. H., \& Dawes, R. A. (1997). State expenditures and policy outcomes in environmental program management. Policy Studies Journal, 25(3), 355-370. https://doi.org/10.1111/j.1541-0072.1997.tb00027.x

Bomberg, E., \& Schlosberg, D. (2008). US environmentalism in comparative perspective, Environmental Politics, 17(2), 337-348. https://doi.org/10.1080/09644010801936263

Carter, N. (2007). The politics of the environment: ideas, activism, policy. (2nd ed.) Cambridge: Cambridge University Press. https://doi.org/10.1017/CBO9780511819179

Dell, K. D. (2009). The grassroots are greener: Democratic participation and environmental policies in state politics. Review of Policy Research, 26, 700-727. https://doi.org/10.1111/ j.1541-1338.2009.00413.x

Gallagher, J. E., Hubal, E. C., \& Jackson, L. (2013). Sustainability, health and environmental metrics: Impact on ranking and associations with socioeconomic measures for 50 U.S. cities. Sustainability, 5, 789-806. https://doi.org/10.3390/su5020789

Jacobson, L. (2013). What We Can Learn from New Hampshire Politics, [Online] Available: 
https://www.governing.com/templates/gov_print_article?id=226328261. (May 29, 2020).

Kodrzycki, Y. K. (2000). New England's Educational Advantage: Past Successes and Future Prospects, New England Economic Review, [Online] Available: https://www.bostonfed.org/publications/new-england-economic-review/2000-issues/issue-jan uary-february-2000/new-englands-educational-advantage-past-successes-and-future-prospect s.aspx. (May 29, 2020).

Konisky, D. M., \& Woods, N. D. (2012). Measuring State Environmental Policy. Review of Policy Research, 29(4), 544-569. https://doi.org/10.1111/j.1541-1338.2012.00570.x.

National Conference of State Legislatures (2020). Composition of State Legislatures by Party Affiliation. [Online] Available: https://www.ncsl.org/research/about-state-legislatures/ partisan-composition.aspx. (May 29, 2020).

National Governors Association or NGA (2020). Gubernational Elections. [Online] Available: https://www.nga.org/ governors/elections/. (May 29, 2020).

Newmark, A. J., \& Christopher, W. (2007). Pollution, politics, and preferences for environmental spending in the states. Review of Policy Research, 24(4), 291-308. https://doi.org/10.1111/j.1541-1338.2007.00284.x

Nicholson-Crotty, J., \& Miller, S. M. (2012). Bureaucratic Effectiveness and Influence in the Legislature, Journal of Public Administration Research, 22, 347-371. https://doi.org/10.1093/ jopart/mur054

Patten, D. M. (1998). The impact of EPA's TRI disclosure program on state environmental and natural resource expenditures. Journal of Accounting and Public Policy, 17, 367-382. https://doi.org/10.1016/S0278-4254(98)10011-X

Steinway, D. M., \& Botts, B. (2005). Fundamentals of environmental law. In T. F. P. Sullivan (Ed.), Environmental law handbook (pp. 1-64), $18^{\text {th }}$ edition. Lanham, Maryland: Government Institutes. https://doi.org/10.1093/jel/eqi039

U.S. Census Bureau (A) (1978-2012). Statistical abstract series. [Online] https://www.census.gov/library/ publications/time-series/statistical_abstracts.html. (May 29, 2020).

U.S. Census Bureau (B) (2020). Glossary of Terms. [Online] https://www.census.gov/glossary/. (May 29, 2020).

U.S Census Bureau (C), (1978-2016). Annual Survey of State Governments, [Online] https://www.census.gov/data/ tables/1999/econ/state/historical-tables.html. (May 29, 2020).

U.S. Census Bureau (2019) New England Quick Facts Table. [Online] https:/www.census.gov/ quickfacts/fact/table/VT,RI,NH,ME,MA,CT/PST045219. (May 29, 2020).

U.S. Department of Commerce, November 2002.Background on the New England Economy. [Online] http://www.buyusa.gov/newengland/index.php?page=28. (May 29, 2020).

Wilcox, R. R. (2005). Introduction to robust estimation and hypothesis testing. Cambridge, MA: Academic Press. 


\section{Copyrights}

Copyright for this article is retained by the author(s), with first publication rights granted to the journal.

This is an open-access article distributed under the terms and conditions of the Creative Commons Attribution license (http://creativecommons.org/licenses/by/4.0/) 